\title{
XXVII. On the electricity of expanding air, as connected with the electrical phænomena of effluent steam
}

\author{
Wm. Geo. Armstrong Esq.
}

To cite this article: Wm. Geo. Armstrong Esq. (1841) XXVII. On the electricity of expanding air, as connected with the electrical phænomena of effluent steam , Philosophical Magazine Series 3, 18:115, 133-134, DOI: 10.1080/14786444108650262

To link to this article: http://dx.doi.org/10.1080/14786444108650262

曲 Published online: 01 Jun 2009.

Submit your article to this journal $\pi$

Џll Article views: 3

Q View related articles $\sqsubset$ 
Mr.W.G. Armstrong on the Electricity of Expanding Air. 133 writing out an investigation with whose results we are familiar.

I request you to insert in your February Number the following correction :

Philosophical Magazine, January 1841, page 9, line 6, read as follows:

"Here $a=0$, and the approximate investigation for $r_{1}$ at the bottom of page 3, does not apply. Remarking, however; that $r_{i}$ is now $=0$, the expression for $\frac{2 \pi}{\lambda} \sqrt{h^{2}+r_{i}^{2}}$ is reduced to $\frac{2 \pi}{\lambda} h+0:$ the term corresponding to $\cos \left(e_{1} \cos \theta\right)$ is $\cos 0$ or 1 : and the term corresponding to $\frac{1}{2 \pi} \int_{\theta}\left(\cos e_{1}\right.$ $\cos \theta$ ) (from 0 to $2 \pi$ ) is $\frac{1}{2 \pi} \times 2 \pi=1$. The expression for the intensity therefore becomes $1+\mathrm{E}^{2} / \pi^{\prime \prime}$

No alteration is required after line 7 , and the results of the investigation are in no way affected.

I am, Gentlemen, yours, \&c.

Royal Observatory, Greenwich,

G. B. AlRy. Jan. 20,1841 .

XXVII. On the Electricity of expanding Air, as connected with the Electrical Phanomena of Effluent Steam. By WM. Geo. Armatrong, Esq.

To the Editors of the Philosophical Magazine and Journal. Gentlemen,

IN connexion with the experiments which $I$ have recently published on the electricity of effluent steam, it occurred to me that it would be well to inquire whether similar effects to those I have described, could be produced by compressing common air in a receiver, and then suffering it to escape in a jet, in the same manner as steam had been discharged from a boiler in the experiments alluded to. With this view, therefore, I condensed about eight atmospheres into a strong vessel, the capacity of which was nearly six quarts; I then insulated the vessel, and discharged the air through a glass tube which I had previously inserted for the purpose.

On the first trial I obtained no indications of electricity whatever, but upon repeating the experiment on a subsequent day, the insulated vessel became so highly electrified, when 
the air was discharged, as to yield sparks fully a quarter of an inch long. I afterwards tried the same experimenta great number of times, and, strange to say, the electricity of the vessel, though generally negative, occasionally proved to be positive. Sometimes the electricity was very strong, and sometimes very weak, and frequently I could get no electricity at all. By means of an insulated conductor terminating in a number of points, I also obtained electricity from the ejected air, and found it to be positive every time I tried it.

I more frequently succeeded in producing an electrical development when the receiver was cold, and contained a little moisture, than when it was warm and dry, so that it is not improbable that evaporation may even here be the source of the electricity. I am by no means sure, however, that my better success when the receiver was cold and damp, was not mere chance, and I only mention the circumstance as a suggestion to persons who may think proper to repeat the experiment.

Newcastle-upon-Tyne, Jan. 23, 1841 .

Wm. Geo. Armstrong.

XXVIII. On Irish Tin Ore. By Aquila Smith, Esq., M.D., M.R.I.A.*

THE question has been often asked, is tin ore found in Ireland? and I believe the only reply which could be given is, that it was said to have been fouud in the county of Wicklow, about the year 1796, when the gold mines were worked on account of the Government.

In the first report on the working of the gold mines, drawn up by Messrs. Mills, King, and Weaver, dated 1st August, 1801 , and published in the second volume of the Transactions of the Dublin Society, the directors state, that " in every instance, where the gold has been found, there have been also found fragments of magnetic iron ore, and quartz containing chlorite, iron ochre, and martial pyrites, attended, more particularly at the works of Ballinvally (on the north-east declivity of Croaghan mountain), with specula iron ore, brown and red ironstone, tin-stone crystals, wolfram, and gray ore of manganese" (Part ii. p. 147.).

Here we find the existence of " tin-stone crystals," announced for the first time in Ireland; and, strange to say, its discovery does not appear to have attracted any attention in a commercial point of view, nor even to have been sought for as a curiosity by the mineralogists of that time; for although many minerals newly discovered in Ireland are briefly de-

* Read before the Geological Socjety of Dublin, Wednesday, December 9 th, 1840 ; and now communicated by the Author. 